\title{
DOCUMENTS
}

\section{The Concept of National Security}

\section{GENERAL PROVISIONS}

1. The Constitution of Mongolia expresses the integrated interests of the people, all groups and strata of Mongolian society.

2. The national security, of Mongolia (hereinafter referred to as "national security") represents the status when favorable external and internal conditions are secured to ensure vital national interests of Mongolia. The ideological basis of the policy ensuring national security is national patriotism.

3. The vital national interests of Mongolia consist in the existence of the Mongolian people and their civilization, in the country's independence, sovereignty territorial integrity, inviolability of State frontiers, relative economic independence, sustainable ecological development and national unity. The vital national interests of Mongolia constitute the object of special care and protection on the part of the State and the people.

4. The endurance of national security implies State policy aimed at creating all-round guarantees of protecting and strengthening of Mongolia's vital national interests, actions taken by the State, its agencies and functionaries to that effect as well as measures implemented by its citizens. Those measures shall be of both preventive and creative nature. Mongolia shall strive to develop its international competitiveness in the economic, cultural, scientific and technological and educational fields.

\section{ONE. Structure of National Security}

5. The national security shall consist of the following main components:

1) Security of the existence of Mongolia,

2) Security of the social order and state system,

3) Security of citizens' rights and freedoms,

4) Economic security,

5) Scientific and technological security,

6) Security of information,

7) Security of Mongolian civilization, 
8) Security of the population and its gene pool,

9) Ecological security

\section{TWO. Factors Affecting National Security}

6. Factors affecting the national security are divided into internal and external by their origins and into immediate, temporary, long-term and permanent by their duration. The vital national interests of Mongolia are interests of a permanent nature.

7. The factors that may have a negative impact on national security are divided into objective and subjective by their character, and into real and possible by the probability of danger they might cause. The policy of ensuring and strengthening the national security aims at identifying and eliminating any threats at the "probable" stage of its occurrence, as well as at reducing or preventing objective threats by the timely elimination of subjective ones.

8. External factors affecting national security:

The national security of Mongolia constitutes a part of the international security and as such is directly dependent on the latter. In terms of political spatial security, it is divided into global, regional and sub regional.

9. Internal factors affecting national security:

In terms of internal spatial dimension, national security shall be of national, regional, aimag, the capital, soum levels.

\section{THREE. Way and Means of Ensuring \\ National Security, Security Guarantees}

10. National security is ensured by social, political, organizational, economic, diplomatic, military, intelligence and legal means, unilaterally or through the development of international cooperation

11. The main means of ensuring national security consists of taking measures designed to forecast and forestall the trends and the development of events on the basis of reliable information and thorough its evaluation and assessment.

12. The main guarantors of national security are the people of Mongolia and the Mongolian State 13. International guarantees of national security consist of political, legal and moral-psychological components. They are secured and strengthened through the combination of unilateral, bilateral and multilateral measures. Military-political security can be ensured through a collective security system by joint efforts or participation in such a system.

\section{FOUR. System of Ensuring National Security}

14. The duties to ensure national security are incumbent on the State Great Hural, the President of Mongolia, the National Security Council headed by the President, the Government, the central and local law enforcement and State ad- 
ministrative agencies.

15. The legislative, executive, judicial and local self-governing bodies are obligated to implement, within their competence, the tenets of this Concept, strengthened by the Constitution, legislation and other relevant legal acts.

16. Political and public organizations, as well as citizens shall strictly observe the legislation on ensuring national security and the present Concept, and shall actively participate in the realization thereof.

17. The National Security Council is charged with the coordination of the strategies and tactics of the implementation of the present Concept with due regard to existing circumstances. It shall monitor the state of safeguarding national security, and annually inform the State Great Hural thereon.

18. The organizations concerned shall provide for funds needed to implement this Concept in their budgets. In cases of special measures, expenses shall be covered by the State budget.

\section{FIVE. Information Database of National Security}

19. Every kind of information necessary to coordinate and implement the State policy of ensuring national security shall be obtained from relevant authorities, citizens, and from foreign sources. The information database shall be set up under the National Security Council.

\section{SECURITY OF THE EXISTENCE OF MONGOLIA}

20. The security of the existence of Mongolia means the endurance of its independence, sovereignty, territorial integrity, and inviolability of state frontiers of Mongolia.

21. External factors which may adversely affect the security of the existence of Mongolia:

1. Armed aggression or threat of armed aggression against Mongolia from any State or force;

2. Policies designed to forcibly abolish the State independence of Mongolia or to disrupt the national unity of the people;

3. Impeding or pressuring the sovereign relations of Mongolia with other States developed on the basis of international law;

4. Organization of terrorist and subversive activities, espionage against Mongolia and its people, as well as the abetting and conspiring in such acts;

5. Imposition by any State of its own interests and policies on Mongolia or attempts to resolve disputes by force

6. Imposition of political, military, economic and ideological control over 
Mongolia;

7. Emergence of global, regional and sub regional crises and conflicts which they may affect Mongolia, or may draw it into war.

8. Destabilization of the Mongolian economy, attempts at or organizing coup detaches or using Mongolia as a bridgehead for policies and activities directed against other States;

9. Changing of state frontiers, illegal border crossing and border violations;

10. Disputes and conflicts between the neighboring States, and being affected by their internal contradictions and crises;

11. Massive inflows of migrants from a neighboring State;

12. Occurrence of natural and ecological calamities, outbreak or spread of acutely infectious human or animal diseases.

22. Internal factors which may adversely affect the national security of Mongolia:

1. Breakdown of statehood, or designs and/or attempts at turning Mongolia into a satellite State;

2. Political, economic and military acts aimed at disrupting national unity and or/ undermining the independence of Mongolia;

3. Emergence of conditions leading to acute religious, ethnic or local disputes and confrontations;

4. Organization of subversive and/or espionage activities aimed at weakening the potential of Mongolia;

5. Division within the armed forces and other military entities, loss of their defense capability or military-patriotic conscience, or confrontation between the military and civilian population or armed insurgency and conflicts.

23. Ways and means to ensure the security of the existence of Mongolia :

Mongolia shall:

One.1) Uphold universally accepted principles of contemporary international law in relations with any State and make others observe them as well;

2) Support the activities of the United Nations Organization and other international institutions aimed at strengthening world peace and security, and closely cooperate with them to that end;

3) Establish and protect bilaterally and multilaterally the legal foundations the unilateral or collective protection of the country from aggression in conformity with Article 51 of the UN Charter;

4) Promote the policy of maintaining strategic stability and establishing a reliable system of strengthening the peace and security in Asia and the Pacific, par- 
ticularly in Northeast Asia and Central Asia;

5) Strictly observe the policy of not allowing the use of the country's territory against other States. Ensure the nuclear-weapons-free status of Mongolia at the international level and make it an important element of strengthening the country's security by political means. Pursue the policy of turning Central Asia into a nuclear-weapon-free zone;

6) Ensure timely and sound reactions to acts capable of affecting or contradicting the vital national interests of Mongolia or damaging its prestige and, if necessary, duly reflect them in the politics and activities of the government;

7) Promote an atmosphere conducive to understanding and supporting Mongolia in other countries, particularly in neighboring and influential countries through the wide use of the policy of "people's diplomacy", an important channel of foreign relations;

8) Promote legal acts that determine the overall number of foreigners and stateless persons that may reside in Mongolia and regulate their movement within the country, and monitor their compliance. Establish a mechanism of control to prevent illegal residence or stay in Mongolia.

Two. 1) Cooperate with other countries and relevant international organizations in the military field, and in pursuit of the policy of safeguarding itself against possible aggression and seeking collective defense, she shall follow the policy of making use of the armed force of neighboring or of third States or the United Nations and/ or other integrated international armed forces;

2) Have national armed forces, other troops capable of safeguarding the country's independence, territorial integrity and inviolability of frontiers;

3) Implement defense objectives on the basis of the universal defense system in accordance with its own military doctrine. In case of having to defend against armed encroachment or aggression solely by its own forces, a self-defense war shall be waged through the mobilization of all internal forces and means while also making wide use of external factors;

4) Participate to the greatest extent possible in international efforts and cooperation designed to strengthen trust in the military field and establish a mechanism for ensuring regional security.

\section{SECURITY OF SOCIAL ORDER AND STATE SYSTEM}

24. Security of the social order and State system means the endurance of the state and socioeconomic structure, fundamental principles of State activities, as well as human rights and freedoms as provided for in the Constitution of Mongolia.

25. External factors which may adversely affect the security of the social order and state system: 
1. Policies aimed at the destruction of the State, and social and economic structure of Mongolia ;

2. Sowing discord among nationalities, different social groups and national leadership in order to disrupt the integrity of the state system, or disrupting the national unity of the people or an attempt to do so;

3. Divulging state secrets including military and technological ones;

4. Espionage activities by foreign intelligence services and their accomplices.

26. Internal factors which may adversely affect the security of the social order and state system:

1. Impair the sovereignty of Mongolia provided for by the Constitution ;

2. Illegal seizure of state power or an attempt to do so;

3. Breach of the equality of forms of property and violation of the right to own property;

4. Breach of principles of non-interference by the state agencies in religious affairs and by religious entities in state affairs;

5. Breach of the principle of separation of State powers of Mongolia ;

6. Emergence of different splinter groups due to difference of views, of ethnic origin, religion, place of origin, contradictions within the national leadership on issues of national security;

7. Weakening of the country's defense potential and the ties between the people and the military;

8.Weakening of the respect for law and order in society, slackening of discipline and responsibility that lead to public disorders, weakening State governance, accountability and vigilance, disclosure of state secrets;

9. Aggravation of corrupt practices taking the form of organized crime;

10. Exhaustion of strategic and other national resources, outbreak of famine and natural calamities, spread of plagues leading to a large number human deaths

27. Ways and means to ensure the security of the social order and state system: Mongolia shall:

One. 1) Enact legislation in compliance with the spirit, principles and provisions of the Constitution of Mongolia, and ensure strict observance thereof;

2) establish a political mechanism for the coordination of activities of political parties and movements;

3) provide conditions needed for protecting the top national leaders from influences contrary to the national interest, and take preventive and safeguarding measures;

4) make government activities transparent to the public except for cases prohibited by law for national security reasons.

Two.1) In foreign relations, exercise political realism and consistently principled approach, according top priority to the vital interests and other national 
considerations, and seek to secure many partners in international relations.

Promote a nonaligned policy so long as it does not threaten the country's vital interests.

Whenever Mongolia's interests conflict with those of other countries, a flexible approach shall be sought bearing in mind the vital national interests of Mongolia;

2) Accord top priority to the question of relations with the two neighboring countries and adhere to the principle of a balanced relationship with them. Maintaining a balanced relationship does not mean keeping equidistance between them or taking identical positions on all issues but this policy does mean strengthening trust and developing all-round good neighborly, relations and mutually beneficial cooperation with both of them. In relations with these countries, due account shall be taken of their policies in regard to the national interests of Mongolia, above all its vital interests. A policy of non-involvement and neutrality shall be pursued in relation to the disputes between the two neighbors unless the disputes affect the vital national interests of Mongolia;

3) Pursue an open foreign policy. Promote the policy of consultation with influential countries on issues of strengthening world peace and security, of developing international cooperation, of enhancing the country's strategic significance and fostering strategic interests of major powers in Mongolia;

4) In its relations with other developing and landlocked countries, pursue the line of jointly defending and promoting the shared interests on the international arena.

\section{SECURITY OF CITIZENS` RIGHTS AND FREEDOMS}

28. The security of the citizens' rights and freedoms means the situation when conditions are ensured for individuals to fully devote their physical and intellectual potential to their own benefit, to the interests of the country and the people, and for Mongolia to carry out its international obligations with respect to human rights.

29. External factors which may adversely affect the ensuring of the security of the citizens' rights and freedoms:

1.Violations of constitutionally, provided and guaranteed democracy, justice, equality and the citizens' rights and freedoms as a result of provocative actions and pressures by other States;

2. Breach of the unity among the population and between citizens by making use of ethnic and religious distinctions, as well as differences of opinion;

3. Restrictions of the rights, freedoms and equal status of Mongolian citizens traveling abroad on business or private trips, or residing there permanently or temporarily;

4. Entrapping of Mongolian citizens by foreign agencies and services through 
promises, incitement and brainwashing and using them to the detriment of Mongolia's interests;

5. Emergence of dual citizenship which would result in the loss of guarantees to ensure the citizens' rights on the part of the State.

30. Internal factors which may adversely affect the ensuring of the security of the citizens' rights and freedoms:

I .Grave violations of human rights provided for by the Constitution and other laws of Mongolia , and by international treaties and conventions to which Mongolia is a party;

2. Lack or loss of real political, economic, social and other guarantees capable of ensuring the citizens' rights and freedoms provided for by the Constitution and other legislative acts of Mongolia;

3. Loss of citizens' sense of patriotism due to hard social and economic conditions.

31. Ways and means to ensure the security of the citizens ' rights and freedoms: Mongolia shall:

1. Guarantee the specific rights and freedoms of citizens provided for by the Constitution of Mongolia through the enactment of relevant legislation;

2. Besides acceding to multilateral treaties and conventions protecting human rights and freedoms, conclude bilateral treaties and agreements ensuring the interests of this country's citizens;

3. Set up a mechanism for providing Mongolian citizens traveling abroad with the needed information on their rights and obligations, on legal means of selfprotection, as well as enhance the role and responsibility of the diplomatic missions of Mongolia abroad in the protection of the rights of citizens;

4. Identify and determine the root causes of political repression, rehabilitate the victims of repression and create political and legal guarantees to prevent the recurrence of such tragedies;

5. Support the activities of the non-governmental organizations aimed at protecting human rights and freedoms;

6. Have the option to introduce appropriate restrictions on human rights and freedoms in accordance with the law whenever the population and the gene pool of the nation are endangered due to the outbreak of acutely infection diseases and disparities in the age and sex ratios of the population;

7. Enact legislation prohibiting dual citizenship and conclude international treaties and agreements thereon;

8. Ensure that the citizens of Mongolia and foreign residents are prohibited from violating the rights and freedoms of others or cause damage to others while exercising their own rights and freedoms, as well as to infringe upon the security and the vital national interests of the country. 


\section{ECONOMIC SECURITY}

32. Economic security means building an economic structure which has the potential for effective economic reproduction through the use of internal resources, for meeting the basic needs of the people and strengthening the country's independence, and in cases of need to sustain the country for a definite period of time.

Economic security represents the cornerstone of the independence and sovereignty of Mongolia.

33. External factors which may adversely affect the ensuring of economic security:

1. Restricting or impeding the development of foreign trade and economic cooperation;

2. Turning into a raw materials appendage to other countries;

3. Plummeting of prices of the country's export items of strategic importance and/or loss of markets for them;

4. Direct dependence on any one country in economic branches of strategic importance.

34. Internal factors which may adversely affect economic security:

1. Failure of the ecological policy leading to the depletion of water and forest resources, reduction of agricultural lands;

2. Widening of disparity in regional development leading to economic unbalances;

3. Depletion of the gene pool of Mongolian domestic farm animals and acclimated varieties of grains;

4. Failure of customs policy leading to penetration of items which may adversely affect the security of Mongolia and its population, to the reduction of sources of budget revenues which may have a negative impact on national production;

5. Increase of the State's current budget deficit, failure of the State policy to protect the national currency, the togrog;

6. A sharp rise in inflation resulting in the fall of the togrog's exchange rate, and increase in the number of families with incomes below the minimum level of subsistence;

7. Growth of the debt to other countries or international organizations and thus increasing the vulnerability to external pressures and dependence;

8. Sharp increase in the number of foreigners and stateless persons resident in Mongolia, and mass emigration of nationally trained personnel and skilled workers;

9. Sharp increase in the share in the overall population of the unemployed, including the number of persons of working age with disabilities.

35. Ways and means to ensure economic security: Mongolia shall:

One. 1) Pursue a uniform government policy in the following fields: 
- economic structural changes - foreign economic relations

- issues related to indebtedness and debt servicing

- budget policy

- monetary policy

- scientific and technological policy

- economic reporting, accounting and information

Two. 1) Recognize the following branches as having strategic importance due to their role in ensuring economic security:

a) in the spheres of production:

- food and agriculture

- mining

- light industry

- chemical industry

b) in the sphere of infrastructure :

- energy

- fuel

- telecommunications and information

- roads and transport

2) Encourage foreign investments in the following areas:

- developing strategically important branches

- increasing the production of export items and foodstuffs

- internally processing raw materials, mechanical components and spare parts thus substituting imports

Three. Pursue the following guidelines in the formulation and implementation of the national policy on ensuring economic security:

1. develop economic and social infrastructures;

2. set up economic zones capable of providing conditions for the relatively independent and integrated development of local areas; 3 . develop industries producing ecologically clean products and introduce waste less technologies;

4. determine, secure and replenish annually reserves of essential food and consumer goods; produce domestically certain types of goods of strategic importance;

5. maintain the country's hard currency reserves at an amount equity the total import costs of not less than two months;

6. protect the gene pool of Mongolian farm animals as well as the acclimated varieties of grains;

7. when developing trade and economic relations with various countries, safeguard against situations where the country's economy, especially its branches of strategic importance, may become the object of dominance by one country, or a group countries or where the country may turn into a raw materials appendage. Impart an interest in the developed countries to freely maintain and expand rela- 
tions with this country;

8. ensure the right of Mongolia to leave access to the sea on the basis of international legal norms;

9. with a view to ensuring economic security, expand bilateral and multilateral equitable mutually beneficial trade and economic cooperation with neighboring countries, and the developed countries of the West and East; secure the country's appropriate place in the regional trade and economic network;

10. keep the amount of strategically important raw materials and equipment to be imported, as well as the number of experts and workers to be received from any one country at the level not capable of affecting national security;

11. avoid situations where incentives and concessions accorded to foreign investors to protect their economic interests surpass the concessions and economic allowances provided to the national investors and producers; oversee compliance therewith;

12. when receiving loans from foreign countries and international organizations, care should be taken so that their total does not exceed the country's capacity to pay back within a specified time period;

13. settle the issues of repayment of loans before 1990 and their interests in accordance with international practices taking into States as well as causes that led to such debts;

14. when promoting the policy of increasing the share of' exports in foreign trade, care should be taken to market processed and finished goods.

Source: https://www.mfat.gov.mn 